\title{
EENIGE BIJZONDERHEDEN OMTRENT HET EILAND BONAIRE.
}

Thans zeker meer dan vroeger is ook in het moederland het eiland Bonaire ter sprake gebragt, daar, zooals de nieuwsbladen ons hebben medegedeeld, de regering voornemens is eenige gedeelten van dit eiland, als ook de zoutpannen, op het einde van dit jaar (1868) in het openbaar te verkoopen. ${ }^{1}$ Dit eiland toch is een domein van Nederland en het is steeds bij vergunning geschied, dat inwoners er zich op hebben mogen nederzetten, landen hebben mogen bebouwen, woningen optrekken en eenig vee houden. $\mathrm{Al}$ wat het eiland daarenboven oplevert, is eigendom van den staat en wordt of van staatswege gebruikt of verkocht. Ik meen dus geen overbodig werk te doen om van dit in het moederland bijna geheel onbekende eiland, thans eenige bijzonderheden mede te deelen en die aan het Koninklijk Instituut van taal-, land- en volkenkunde van Nederlandsch Indië ter verder verspreiding aan te bieden, waartoe ik mij bevoegd mag achten, daar ik onderscheiden keeren op dat eiland gedurende eenige weken wegens dienstzaken vertoefd heb en dus met den toestand aldaar bekend ben.

De onderhoorigheden van Curaçao zijn: de eilanden Bonaire, Aruba, St. Martin (gedeeltelijk), St. Eustatius en Saba, die, ieder door eenen gezaghebber, door Z. M. den Koning te benoemen, worden beheerd. De naam van eerstgenoemd eiland, eigenlijk: bon aire, goede, gezonde lucht, is, men weet niet wanneer, aan dit eiland gegeven. Het handhaaft echter nog altijd zijnen ouden naam en roem daar ziekelijke menschen van Curaçao en van de Spaansche kust meermalen Bonaire bezoeken, om hunne gezondheid te herkrijgen, hetgeen dan ook somtijds gelukt. Of echter dat herstel van gezondheid aan de meer gezonde luchtgesteldheid van Bonaire boven

1 Sedert zijn, 20 Sept. 1868, publiek op Curaçao verkocht het grootste gedeelte der domeingronden. (Zie de Bijlagen hierachter). 
Curaçao en de kust moet worden toegeschreven, zou ik betwijfelen. Indien er verbetering in het gestel van ziekelijken wordt waargenomen, zou ik dit grootendeels toeschrijven aan verandering van plaats, van bezigheden, van gewoonten; vooral omdat men zich dan bijzonder op het wandelen des morgens en tegen den avond toelegt, dus de vrije lucht meer inademt, en er.gratuite zeebaden kan gebruiken. Bonaire toch kan, wat de luchtgesteldheid aangaat, van Curaçao weinig of niets verschillen, omdat die eilanden, even als Aruba in ééne rij als het ware nevens elkander gelegen zijn en uit dezelfde gronden zijn zaamgesteld, misschien met weinige uitzonderingen, ten aanzien van de steensoorten. Zooals bekend is, wordt op Aruba goud en koper gevonden (van daar welligt zijn naam, verbasterd van Oroba of Auroba) hetgeen men op Curaçao en Bonaire nog niet ontdekt heeft. Maar op alle drie de eilanden is het rotsig, bergachtig, droog en winderig; dezelfde planten en boomeu groeijen er, dezelfde soorten van vee telen er op voort, men gebruikt er hetzelfde voedsel. Men heeft er, ja, vrije doorspeling van den wind, zonder togt, omdat de weinige huizen die er zijn, allen van elkaar afliggen; doch dat heeft ook op Aruba plaats en ik heb nooit gehoord dat ziekelijken dit eiland bezochten om te herstellen. Diezelfde luchtgesteldheid kan men ook op Curaçao ondervinden, zoodra men het stadsdistrict verlaat en zich in de buiten-divisien ophoudt. Maar evenals op Curaçao en Aruba kan het op Bonaire sterk waaijen. Die voortdurende wind evenwel, welke slechts in weinige maanden of gedeelteu van maanden (October-December) niet waargenomen wordt, vooral als het dreigt te regenen, zal zeker veel tot de gezondheid op de drie genoemde eilanden te weeg brengen, daar ook de warmte-temperatuur op alle dezelfde en altijd vrij hoog is.

Bonaire, welks bergen of rotsen men van den noord- en oostkant van Curaçao met het bloote oog bij helder weer duidelijk zien kan, ligt ten oosten van Curaçao, zich evenals dit van het oosten naar het westen, op niet zeer groote breedte, gedurende eenige uren uitbreidende. Het heeft geen haven, maar eene veilige reede, baai genoemd, waarin ook diepgaande schepen tot digt bij het strand kunnen ankeren. Deze baai, welker strekking tegen het westen is, wordt gevormd door een eilandje, Klein-Bonaire genaamd, dat op een half kwartier afstand van Bonaire gelegen, zich, bij geringe breedte, een half uur ongeveer vóór de reede in de lengte uitstrekt. Naar dat nu de wind 3e volyr. III. 
het toelaat, kan men van Curaçao of elders komende, noordwaarts of zuidwaarts van dat eilandje, op de reede of in de baai een veilige anker- en ligplaats vinden. De baai zou groot genoeg zijn om honderde schepen te bevatten; gewoonlijk ziet men er niet meer dan 2 tot 6 barkjes (énmast vaartuigjes) of kleine schoeners in liggen, daar het eiland geen handel drijft. Die reede, veilig bij oost-, noord- en zuidelijke winden (gewoonlijk waait de wind uit die streken) wordt alleronveiligst en gevaarlijk bij westelijken wind en stroom, die de schepen welke voor anker liggen, indien zij niet dadelijk bij het opkomen van den wind zee kiezen, al zeer spoedig op het strand zetten, voor groote schepen met zeer weinig hoop om er af te komen; welk ongeluk den 24sten Junij 1831 overkwam aan 'slands oorlogschip, de brik de Sirene, kapt.-luit. C. van der Hart, omdat het bij het omslaan van den wind niet tijdig genoeg zee had kunnen kiezen. De manschap, die gelukkig gered werd, werd gehuisvest in de roomsch katholieke kerk en het etat-major bij de ingezetenen. Later werden zij naar het moederland overgevoerd met het transportschip Dordrecht.

Dat Klein-Bonaire schijnt klaarblijkelijk in vorige eeuwen van Bonaire te zijn afgerukt. Het is ook steen- of rotsachtig, maar laag en slechts met struikgewas bedekt; er wordt eene kudde kabrieten (soort van reebokken of gazellen) door het gouvernement op gehouden en heeft een strand van zeer fijn, wit zand, hetgeen dan ook elders zeer gezocht is, maar toch geen belangrijk artikel van handel uitmaakt, daar de scheepjes van Bonaire het gewoonlijk als ballast medenemen. Het is een aardig uitstapje of liever overvaartje van Bonaire naar Klein-Bonaire, als des achtermiddags de zon wat begint te duiken. Jammer maar dat er slechts ééne woning is, een gouvernementshuisje, wat landwaarts in, doch in welks nabijheid een goede put is met zoet water; er moeten ook nog andere putten zijn, hetgeen wel te verwonderen is, wegens de geringe breedte van het eilandje. Bij het heenvaren moet altijd iemand tegenwoordig zijn, die met het strand bekend is, daar men slechts aan den oostkant op ééne plaats met de boot kan landen of eigenlijk veilig op strand loopen; mist men die, dan stoot men op klippen, woelt in het zand en blijft vastzitten.

Zulk een landingsplaats, doch aan de westzijde, derhalve beneden 's winds, heeft ook het eilandje Klein-Curaçao, dat men op deu togt van Curaçao naar Bonaire voorbij moet en dat 
door een van wege het gouvernement gehuurd vaartuig, eens in de week heen en weer, moet worden aangedaan. De vaart van Curaçao naar Bonaire moet altijd, omdat dit laatste boven wind en stroom ligt, tegen stroom en wind op geschieden; zeer zelden is dit ongekeerd. Is de stroom sterk, hetgeen eenige maanden in het jaar, vooral in het begin van het jaar en omstreeks St. Jan het geval is, en is de wind oost of zuidoost, dan kan de vaart wel eens van 2 tot 5 à 6 dagen duren; ja, meermalen gebeurt het, dat de scheepjes die de haven van Curaçao zijn uitgeloopen, na één of twee dagen te vergeefs tobben, genoodzaakt zijn den steven te wenden en de haven weder binnen te loopen, uit gebrek aan proviand en water. Bij goeden wind geschiedt de overvaart van Bonaire naar Curaçao gewoonlijk in 6 uren. Nagenoeg op de helft van den afstand tusschen de beide eilanden ligt het genoemde KleinCuraçao; dat een nog lager dan Klein-Bonaire liggende klip is, waarop slechts een zeer enkele boom groeit, en ook soms nog wat brak gras dat bij groote droogte en gebrek voor het vee en bijzonder voor de paarden, naar Curaçao wordt vervoerd. Wegens de gevaarlijke ligging van dit eilandje, dat zich ook bij zeer geringe breedte een kwartier van het noorden naar het zuiden uitstrekt en wegens de zware branding op de klippen aan de oostkust, waarop menig schip reeds vergaan is, is daar van gouvernementswege in 1849 een baak of vuurtoren gebouwd, de "Prins-Hendrik-toren" genaamd, die van 6 ure des avonds tot 6 ure des morgens een helder wit licht vertoonende, tot zeer veel nut is. De wachter met zijn huisgezin, assistent en twee of drie knechts, te voren landslaven, zijn de eenige bewoners van dit armzalig eilandje, waar niets te vinden is, wat tot voedsel zou kunnen dienen, niet eens drinkwater; alles moet hun van Curaçao worden aangevoerd, daar ook de regenbak, welke tegen den vuurtoren is aangebouwd, zeer weinig water ontvangt en dan nog gewoonlijk brak, wegens de zoutdeelen die tegen het dak en de muren slaan en er zich in vasthechten. Het eenige waarmede de wachter en zijn assistent zich over dag bezig houden en waarmede zij ook nog iets verdienen boven hun karig tractement, is de vischvangst. De visch wordt dan gezouten en gedroogd. naar Curaçao ten verkoop vervoerd. Is het de tijd, dan verzamelen zij ook boebie- (eene soort van meeuw) eijeren, die veel overeenkomst net kiewitseijeren hebben, ook wat den smaak aangaat, koken die even op en geven ze 
naar Curaçao mede. De laatste jaren waren in dat opzigt echter onvoordeelig, omdat het aantal boebies jaar tot jaar vermindert. Niet eens een kabriet kan op dat onherbergzaam eilandje gehouden worden voor de melk, omdat er geen genoegzaam voedsel voor het dier wordt gevonden en vooral geen water en het te veel moeite schijnt te ziju, dit voor eenige weinige stukken klein vee van Curaçao aan te voeren. En toch, als men er van Curaçao aankomt, schijnt het heen en weer zwieren van duiven, welke de wachter er op na houdt, de doodsche stilte van die klip eenigzins weg te nemen, terwijl het 't Nederlandsche hart goed doet, meer dan men zou denken, dat te midden der zee op dat kleine plekje gronds, de vaderlandsche driekleur wappert. Voor eenige jaren werd dit eilandje ook als quarantaineplaats gebruikt voor schepen, die op Curaçao niet mogten binnenloopen, en dan werd er eene wacht soldaten heengevoerd. die alle gemeenschap met het eilandje en met de schepen, die er voor geạ̣kerd lagen, moest beletten. Dat was waarlijk een post! De baak, van steen opgetrokken, wordt wel gedurig door zeeën en winden geteisterd, doch schaden dien niet. In het laatst van 1859 was er door hooge zee en hevigen storm een goed gedeelte van het noordelijk strand weggeslagen, met 5 van de 6 eenige kokosboomen, welke er zich bevonden, zoodat er nu nog slechts één schijnt te staan treuren over het lot zijner makkers, dat hem ook weldra wacht of misschien reeds getroffen heeft. Nieuwe dáár aan te kweeken schijnt thans onmogelijk.

Wanneer men nu, bij een niet al te sterken stroom of te veel oostelijken of zuidoostelijken wind, op den middag $\mathrm{Cu}$ raçao verlaat met de gouvernementsbark, dan is men met of vóór het aanbreken van den volgenden dag bij Klein-Curaçao. Een vaartuig, dat dit eilandje niet behoeft aan te doen, kan den overtogt naar Bonaire in één of anderhalven dag doen, doch een goed bezeilde schoener werkt er ook wel eens drie of meer dagen over. Het reisje naar Bonaire is voor een landrot alles behalve aangenaam op zoo'n barkje, want al strekken zich kapitein en matrozen, als het donker wordt, al spoedig op de planken uit om te slapen, behalve den man, die aan het roer staat te hangen en te dutten, voor een passagier, die te huis aan meer gemak gewoon is, al is hij het slapen op veren bedden afgewend en al kan hij zich best op een matras of matje of ezel of in een hangmat ter ruste begeven, is het in het kajuitje, 
dat met allerhande zaken is volgepropt, waarin hitte en benaauwheid en allerhande onaangename scheepsluchten zich verzameld hebben, zeer slecht gedurende eenige uren uit te houden; hij blijft dan liever 's avouds of 's nachts op het dek zitten in het water te kijken of in de lucht, waarin hij de allerhelderste sterren ziet schitteren, waarvan sommige zelfs eene lichtende streep op het water vertoonen, of hij ziet die sterren aan de oosterkimmen opgaan en klimmen en anderen haren weg aan den hemel vervolgen, dalen en ondergaan. 't Is dan ook op zulk een barkje nog aangenamer als het donker is dan over dag. Naauwelijks toch is de zon, bij weinig voorafgaande morgenschemering, opgegaan, of, spoedig geklommen, doet zij haren gloed reeds gevoelen en doet dit al meer en meer, hoe hooger zij stijgt, totdat men, daar er geen zonnetent kan gespannen worden en men het onmogelijk in de gloeihitte van het kajuitje kan uithouden, zoowat half gekookt en gebraden, ten minste letterlijk geblakerd wordt van de zon, waarvan men op handen, aangezigt en nek nog eenige dagen lang de kenteekenen en wel gevoelige kenteekenen draagt. Dan verstompt de hitte en de gloed alle hoogere opwekking en overdenking en men hijgt, bij het drinken van al wat maar verfrisschend kan heeten, indien men het heeft en anders van een laauwen of ook wel warmen dronk water (want het watervaatje staat ook in de zon of ligt in het gloeijend ruim), naar het tijdstip dat de zon niet alleen daalt, (want die dalende zon is door hare schuinsche stralen nog hinderlijker dan de hoog staande), maar dat zij aan den westelijken horizont in het zilte nat nederzinkt.

Nadat men om de zuidpunt van Klein-Curaçao is heengevaren, ziet men de Curaçaosche kust al onduidelijker en die van Bonaire duidelijker worden, ja, men zou meenen in weinige uren op dat eiland te kunnen aanlanden, indien niet, zoowel de afstand uw oog bedroog, als wind en stroom het verhinderen. Men zeilt dan dien dag maar door, dan over den eenen boeg, dan weder over den andere. Den kost moet men zelf medebrengen, alhoewel vergund wordt het vleesch, dat men bij zich heeft, in den eenigen ijzeren pot, die aan boord is en waarin alles gekookt wordt, wat op te warmen. Heel keurig moet men niet zijn. Een passagier zit zich zoo'n dag mooi te vervelen en de vraag hoe laat of hoe vroeg men op de reede van Bonaire zou zijn, wordt nog al eens herhaald. Eindelijk is midden in dem nacht die reede bereikt en het anker uitgeworpen, 
Zoodra de dag aan den hemel was, trachtte ik zoo spoedig mogelijk in een boot naar wal te komen. Het gezigt op de reede is niet onaardig. Men ontwaart eerst den toren van de roomschkatholieke kerk, die landwaarts in staat, in de dusgenoemde Savannah; dan het torentje van het protestantsche kerkje, digt bij den dijk gelegen en het hoog uitstekend gouvernementsgebouw, de woning van den gezaghebber. Het fortje (indien het dien naam dragen mag) wordt aangeduid door eene vlag. Komt men van den noordkant binnen, dan vaart men eerst eenige kleine huisjes voorbij, die op den zeedijk, op onregelmatigen afstand van elkander zijn gebouwd en er onaanzienlijk uit zien, totdat men het hospitaal of ziekenhuis gewaar wordt, dat al vrij *wonderlijk in elkaar zit, doch in de laatste jaren, naar ik verneem, groote verbeteringen heeft ondergaan. Daarna beginnen de huizen wat grooter te worden, eenige ten minste, ze staan wat meer op of bij elkander; het heeft iets van een dorp, dat niet groot is.

Het gouvernementshuis is een groot, fraai gebouw, aan den zuidkant met een ruim boven balkon; onder het gebouw zijn gouvernements pakhuizen en kantoren; voor het gebouw eene groote plaats, Koraal geheeten, met vrij hoog opgeschoten kokosboomen Het geheel is met een hekwerk omgeven. Ten zuiden van het gouvernementsgebouw is het fortje, eene soort van vervallen bastion, in een van welks schietgaten een oud, onbruikbaar kanon ligt te verroesten; aan dat fortje is nog een gouvernementshuis verbonden, dat ter beschikking van den gezaghebber is. Verderop zijn nog eenige verspreid liggende, door rolsteenen paden verbonden woningen, en men heeft Kralendijk, zooals het dorp geheeten wordt, reeds bekeken. Op den naam van stad kan dit plaatsje zeker nog niet bogen, evenzoomin als dat aan de baai op Aruba, ofschoon men dit verheerlijkt heeft met den grootschen naam van Oranje-stad. Kralendijk is eene zeer gepaste en nederige benaming, op waarheid gegrond, want de dijk, waarop de woningen staan, is van kralen, dat is: van steenen, die door de golving der zee afgerond en opgeworpen zijn; ook rolsteenen 'genoemd, niet groot van stuk, maar zeer ongemakkelijk om er op te loopen. Breed en hoog is die dijk niet en ik geloof ook niet zeer vast, zoodat hij bij westelijken storm en hooge zee al spoedig doorwoeld en omgewoeld zou ziju en de woningen omvergeworpen. Doch van die voor andere eilanden der Karaibische zee zoo gevreesde rampen heeft 
men op Bonaire, zoomin als op Curaçao en Aruba vrees te koesteren en men woont dan op den dijk veilig en luchtig. De laatste storm en hooge zee, die men zich op die drie eilanden herinnert, hadden plaats in October 1807.

$\mathrm{Nu}$ zijn er in de Savannah, eene woeste vlakte die bij eenigen regen dadelijk onder water staat doch spoedig opdroogt en een ware stofwoestijn is, noord- en oostwaarts digt bij den dijk eenige vrij goede en ruime huizen gebouwd, onder welke ook dat behoort, waarin de zusters der liefdadigheid wonen, gewoonlijk nonnen genoemd, en die eene school hebben ingerigt. Het huis wordt al met den naam van klooster bestempeld. In de nabijheid daarvan is de op zich zelf staande, vrij ruime en eenvoudige, doch net ingerigte roomsch-katholieke kerk; de ruime pastorij grenst er aan. In de nabijheid daarvan zijn weder eenige kleine woningen, doch die fraai gelegen zijn, daar de tusschenruimte, waarin zij van elkander staan, door wat boom- en struikgewas is gevuld; men noemt dat gehucht: Rieba piedra, dat wil zeggen: boven op de steenen, omdat het er zeer klippig is. Even toch als op Curaçao en Aruba is de landtaal er het dusgenoemde papiameutsch of kreoolsch. Vóór weinige jaren is de roomsch-katholieke kerk wel voor de helft vergroot en de toren aan den westkant met een luiklok er in, levert een goed gezigt op, en is vooral des avonds, als het wat donker is, een goede baak om den weg te vinden. Want de hoofdweg naar het binnenste des eilands, evenals de andere wegen, die ik op Bonaire gezien heb, die goed onderhouden wordt, loopt er langs. Verder op, oost- en zuidwaarts, rijn twee buurten, uit verspreid liggende woningen bestaande, de eene Mundo nobo of de nieuwe wereld genoemd, de andere Nikiboko; de beteekenis van dit laatste woord heb ik niet kunnen te weten komen, boko beteekent een vat. De bewoners dier gehuchten telen wat maïs, houden er wat kabrieten op na, gaan watapana (dividivi, eene soort van peul om te loogen) zamelen, of verwhout hakken en zoeken dus op alle mogelijke wijze aan den kost te komen. Deze lieden, zwarten of kleurlingen, geëmancipeerde slaven of vrijlieden, zijn allen, zonder eenige uitzondering, roomsch-katholiek, doordien hier zoowel als op Curaçao de protestantsche eigenaars van slaven, al de uit deze geboren wordende kinderen, roomsch lieten doopen, om daardoor een afstaud te stellen tusschen hen en de slaven. Thans breidt zich dan ook die gemeente bij den dag 
uit. De protestantsche gemeente is tegenover de ruim 2,000 roomsch-katholieken een klein kuddeke van ongeveer 150 zielen, meestal gouvernementsambtenaars met hun gezin, over welke eerst in 1859 een leeraar is aangesteld. Te voren kwamen de predikanten van Curaçao om het halfjaar dienst doen en nam een godsdienstonderwijzer, tevens schoolmeester, op zon- en feestdagen er de kerkdienst waar, evenals op Aruba, (waar in 1858 een predikant kwam,) op eene gouvernementsbezoldiging van $f 200$ 's jaars; daarvoor moest hij tevens godsdienstig onderwijs aan de jeugd geven. Het kerkje behoeft daarom ook maar klein te zijn; de vorm er van is langwerpig vierkant, net en goed ouderhouden. In den noordelijken gevel is een bel of luiklok aangebragt, waardoor de gemeente wordt gewaarschuwd als het tijd is om ter kerk te komen, want een publiek uurwerk is er op Bonaire niet, men moet maar zoo wat gissen naar den tijd, en klokken en horologies worden gelijk gezet als de juiste tijd door een vartuig van Curaçao wordt aangebragt. Dit kerkje werd vooral door de zorg van Ds. A. J. K. Meijer, van Curaçao, in 1847 gesticht, uit vrịjwillige bijdragen der gemeente op het eiland en op Curaçao; vóór dien tijd werd er kerk in het schoolgebouw gehouden.

Het drinkwater is er zeer schaarsch. Weinige regenbakken vindt men bij de in de laatste jaren van steen opgetrokken huizen. Te voren waren alle huizen, zooals er ook nu nog tusschen de anderen verspreid liggen, hutten van teenen of twijgen met klei aangestreken en dan gewit; de vloeren zijn ook nog in vele, zelfs steenen huizen, uit kalk en tras vervaardigd, waarover men zand strooit. De in de nabijheid der reede gegraven putten geveu allen brak water. Het putwater, dat drinkbaar is, moet dus op verren afstand in vaten door ezels worden aangebragt. Deze viervoeten zijn op Bonaire zeer in gebruik en men berijdt ze ook in plaats van paarden. Het eiland levert wilde ezels op, dat is: zulke die in het wild in de bosschen rondloopen en daar voorttelen; jaarlijks worden er nog eenige honderden opgevangen en verkocht, zooals ook eenige wilde paarden en stieren. Die dieren hebben echter veel van de droogte te lijden, die ook gewoonlijk op Bonaire heerscht, zoodat in de laatste jaren er velen van gestorven zijn en men de wilde paarden slechts nog op een 50 tal schat. Men ziet deze meermalen bij. troepen in de Savannah, digt bij de reede; zij zijn niet zeer schuw, hebben eene flinke gedaante en zijn goed gebouwd. 
De stieren, die men soms opvangt, evenals de paarden met de lasco, zijn schoone, goed gevulde, sterke beesten, die warlijk eene hollandsche tentoonstelling van vee geen schande zouden aandoen, maar wel integendeel de bewondering van iedereen wegdragen. Kabrieten, wier vleesch zeer goed is, zijn er iu menigte, schapen in minder groot getal. Particulieren mogen ook eenige kleine kudden schapen en kabrieten houden en die vrij laten weiden, zij groeijen echter wel eens tot een sterker aantal aan, dan geoorloofd is; doch het is zoo moeijelijk die beesten te telen. Het gouvernement bezit zelf eene schoone kudde hoornvee, koeijen en kalveren, ook eene kudde schapen. Het aantal kabrieten van het gouvernement moet te voren verscheiden duizenden hebben bedragen, doch is langzamerhand, men weet wel waardoor, tot eenige honderden geslonken. De huiden der kabrieten tot het vervaardigen van leder zijn zeer gezocht en worden daarom ook uitgevoerd.

De grootste opbrengst echter, ten bate van het gouvernement, leveren de natuurlijke zoutpannen. Deze zijn zuid- en zuidoostelijk van den Kralendijk gelegen, eenige op wel 4 à 5 uren afstand, in wier nabijheid zich de vuurbaak, de Willemstoren geheeten, bevindt, die in 1837 gebouwd is. Zij leveren zeer goed zout op, dat zeer is gezocht en waarvan jaarlijks duizende vaten vooral aan Amerikanen worden afgeleverd tot den prịjs van 75 cents en minder het vat van omstreeks 300 amst. ponden. De opbrengst van die zoutpannen makt dat Bonaire het eenige eiland is van de zes (Curaçao en zijne onderhoorigheden) dat voordeel voor het gouvernement afwerpt, nadat alle uitgaven, ook voor de ambtenaren zijn afgetrokken. Ik heb die bate wel tot $f 80,000$ uitgetrokken gezien. Er moeten onderscheiden gouvernements-ambtenaren op Bonaire zijn, omdat er betrekkelijk veel is na te gaan en te bewaken. Want behalve de zoutpannen en het vee zijn er ook nog gouvernementsplantages, waar te voren cochenille, nu meest aloë, gekweekt wordt, zooals Guatimala, Mexico, Amboina, Fontein. Eene merkwaardigheid van Fontein, op aanmerkelijken afstand van de reede naar het noord-oosten gelegen, waaraan zij ook haar naam ontleent, is eene altijd loopende bron, welke uit een spelonkje te voorschijn vloeit en zich met een kleinen straal in een grooten gemetselden vergaarbak ontlast, waaruit het water naar eenige onder elkander liggende terrassen kan geleid worden; deze worden gebezigd tot het aankweeken van eenige groenten. Bij 
het huis, dat op eene rots ligt, is ook eene laan van kokosboomen. Fontein kan een waar lustoord van Bonaire zijn, ook door zijne koele ligging en aangenaam uitzigt op zee.

Van de reede deed ik met eenige andere heeren, door den gezaghebber daartoe uitgenoodigd, een uitstapje naar Fontein; op ezels waren wij gezeten en niet op paarden, omdat deze wegens de aanhoudende droogte te slap waren; 't was toen in November en het had nog bijna niets geregend. De ezels waren ook niet sterk en als de knechts er niet met stokken hadden achter gezeten, zouden wij slecht op onzen togt voortgekomen zijn. 't Was nu wel geen cavalcade, maar een boericade (boerikoe is in het kreoolsch: ezel). Stapvoets ging het langzaam vooruit. De weg was goed, soms wel wat ongemakkelijk, als het berg af moest; dan marcheerden wij ook wel eens te voet, om het onzen beesten wat ligter te maken. 't Ging anders langs weigroen, kreupelhout, soms langs redelijk hoog opgeschoten houtgewas. Op de helft van den weg, toen wij een anderhalf uur in den vroegen morgen hadden afgelegd, moesten wij een uurtje stilhouden en afstijgen, zoowel om onze ezels wat te laten uitblazen en zich met een mondvol droog gras of bladeren te laten bijhalen, als om zelven eenige verversching te nemen, die de knechts en meiden op hun hoofd ons nadroegen, waarop ook geladen was, wat wij op Fontein zouden behoeven, om honger en dorst te stillen. Toen de beesten wat uitgerust waren, ging het wederom verder en zagen wij eindelijk na 9 ure de open zee voor ons en dat was het teeken, dat wij den eindpaal van onzen togt nabij waren. $\mathrm{W}_{\mathrm{ij}}$ waren ondertusschen reeds zeer warm, daar de zon al hooger en hooger stijgende, ons met hare brandende stralen reeds begon te blakeren. Dit verhinderde echter niet, dat toen wij op Fontein aangekomen waren, wij de bron, het water, de terrassen, groentebedden en kokosboomen in oogenschouw namen, en ons vermanden om de wel breede, maar toen in zeer vervallen staat zijnde 25 trappen, naar het bijna in puinhoop liggende huis op te klimmen. Later, onder een anderen gezaghebber, is dat alles hersteld. Wij werden echter onder het plat van riet of maïsstokken opgetrokken dak, in eene kamer of gaanderij zonder jaloeziën, waarin de wind vrij spelens had, door den gezaghebber zoo comfortable mogelijk ontvangen. Er werd een tafel en een paar stoelen uit de toenmalige slavenhutten en uit die van deu bomba (opziener, meestal een vrijgemakte) naar 
bovengebragt, met nog eene bouwvallige bank en wij konden weldra gaan zitten aan een krachtig ontbijt. Nadat wij ons daardoor en door een glas wijn en daarna een kop koffij wat versterkt hadden, ging de een wat in de hangmat, - want die hadden wij medegenomen, -- rusten, terwijl de anderen zich vermaakten met quadrille spelen.

Toen te 11 ure de pastoor van het op een klein uur afstands gelegen dorp Rincon, den gezaghebber en zijn gezelschap was komen begroeten en nu ous getal door den pastoor en den ambtenaar, die op Fontein woonde, met twee was vermeerderd en er volstrekt geeu zitplaatsen voor de aanwezigen waren, werd er, met goedvinden van den pastoor besloten, dat wij gezamelijk naar zijn dorp zouden rijden, al het eten, dat reeds klaar was gemaakt, zouden medeuemen en wij in de pastorij zouden dineren. Ofschoon het nu wel wat warm was, om op het midden van den dag naar den Rincon te rijden, zoo werd er besloten den etenstijd wat te verschuiven en wij reden klokke half 5, regt tegen de zon in, door een besloten weg, den wind van achteren, op onze ezeltjes gedurende een groot half uur, zoodat wij voor de avondschemering aankwamen en nog den tijd hadden de kerk te zien, voor welke sedert een nieuwe gebouwd, terwijl de oude kerk tot school ingerigt is, eenige woningen of hutten voorbij en in te gaan, die in het dorp, ruim 600 zielen sterk, tusschen tuinen verspreid liggen. Met een hongerige maag keerden wij in naar de pastorij, die pas nieuw van steen was opgetrokken, er zeer netjes uitzag en genoegzame ruimte had voor den pastoor om er met zijne huishouāster, nog een jong mensch maar die familie van hem was, te wonen. De wijnkelder van den pastoor scheen wel voorzien te zijn, want behalve den wijn, dien de gezaghebber er had laten heenbrengen, werd er nog menige flesch ontkurkt en onder aangenaam gesprek leeggedronken, waaraan echter de huishoudster, hoewel aan tafel gezeten, geen deel nam.

De Rincou (den oorsprong der benaming wist men mij niet op te geven) was voor eenige jaren slechts een klein gehucht, uit eenige armzalige hutten bestaande; langzamerhand echter vermeerderde de bevolking, omdat het aangenaam in een dal is gelegeu en de grond, behalve eenige rotsachtige plekken, zeer vruchtbaar is. De putten, die groote diepte hebben, leveren ook overheerlijk drinkwater en in genoegzaam overvloed, zoo- 
dat men daaraan nooit gebrek heeft. Daar het allen vrijlieden waren (vrijgelatenen vóór de emancipatie) en hunne afstammelingen en allen de R. K. godsdienst beleden, werd er bij de uitbreiding van het gehucht al spoedig behoefte gevoeld zoowel aan kerk en geestelijke, als aan school en onderwijzer. In het een en ander werd door medewerking van het gouvernement voorzien, daar het ondoenlijk was voor de inwoners, èn aan de reede te kerk te gaan èn hunne kinderen dáár ter school te zenden. De inwoners, kleurlingen en zwarten, die er allen sterk en welgedaan uitzien, vinden hun onderhoud in den landbouw, dat is: het planten vau mais, boontjes, erwten en het houden van kabricten, wier vleesch zij eten en de huiden verkoopen. Zij kweeken ook eenige vruchtboomen aan, en hebben door het een en ander genoeg om in hun onderhoud en weinige kleeding en meubelen te voorzien. Doch zij leven afgescheiden van de wereld en als er dus bij toeval eens een vreemdeling komt, wordt hij door klein en groot aangegaapt, zooals ons gebeurde, ofschoou er eeuigen onder ons waren die zij kenden. Van het Nederduitsch wist slechts een iet of wat, namelijk de dusgenaamde schoolmeester; dat is er dan ook geen behoefte, want de geheele bevolking spreekt kreoolsch, de pastoor preekt in het kreoolsch, alhoewel die een Nederlander is, en de schoolmeester heeft boeken of boekjes in die taal, waaruit hij de kinderen leert lezen, die gedrukt zijn op de roomsch-katholieke Santa Rosa op Curaçao. Na den eten, dat nu een souper was geworden, daar het bij lamplicht geschieden moest, een kop koffij gedronken en wat sigaren gerookt hebbende, bedankten wij onzen vriendelijken gastheer en reden welgedaan en nu heel wat frisscher dan in den namiddag, in den avond en in het donker, want het was donkere maan, naar Fontein terug en kwamen er nog vroeg genoeg aan, om bij eene vetkaars, die in eene flesch gestoken was, nog wat te zitten praten en een glas wijn of grog te drinken.

Ofschoon een paar van ons gezelschap plan hadden gemaakt den volgenden dag den hoogsten berg op het eiland, Blandaar genaamd en een half uur van Fontein gelegen, te beklimmen, en dit ook hebben uitgevoerd, doch onder aanhoudenden regen, zoodat zij alles behalve pleizier hadden van hunnen togt, -- reed ik met den schoolmeester, daar wij beiden dien Woensdag dienst hadden, in den vroegen morgen naar de baai terug, door een knecht vergezeld, die goed den weg wist, Wij namen namelijk 
nu een geheel anderen weg dan den vorigen dag, door den dusgenoemden montanje. 't Was een fraaije weg, zooals men alleen in bergachtige streken hebben kan. Eerst ging het zacht glooijend opwaarts, soms wat meer steil, maar altijd op een niet heel breed, doch goed gebaand pad, door opgaand, frisch groen geboomte heen, dat ons ook de noodige schaduw gaf. Van tijd tot tijd werd dit boschgezigt afgewisseld door maïsvelden, waarop het koren reeds was opgeschoten, of die men bezig was te bewerken. Een enkele stulp reden wij voorbij of zagen die in de verte; want behalve Kralendijk, Rincon en de buurten, die ik heb opgenoemd, is het eiland onbevolkt, alleen hier en daar wordt een huis of huisje gevonden, door een tuin of veld omgeven. Wij bereikten, na een goed uur rijdens, het hoogste punt van den montanje; in het afdalen was het soms veiliger van den ezel af te klimmen en te voet te gaan, daar èn het dier zeer zwak was èn het pad zeer steil en belegd met rotsblokken. Onder het afdalen, dat vrij moeijelijk en langzaam ging, hadden wij echter een overheerlijk gezigt op de geheele kust van het eiland, van het noorden naar het zuiden, op den Kralendijk, Klein-Bonaire en de open, kalme zee. Waarlijk het was schoon! En hoe meer wij afdaalden, zagen wij groene mäsvelden in de vruchtbare dalen. Lindelijk hadden wij den voet van het gebergte bereikt en het vergezigt was verdwenen, maar niet het groen geboomte, niet de werklieden op het veld, deze werden menigvuldiger, zooals ook de landelijke woningen, totdat wij ten laatste weder op den weg uitkwamen, dien wij gisteren genomen hadden en ik na eenige minuten rijdens aan de woning afsteeg, die ik in de Savannah, digt bij de roomsch-katholieke kerk betrokken had. Wij hadden ruim drie uren gereden en het werd tijd ons voor de stralen der zon, die nu vlak op ons begonnen neder te schieten, te beschutten. Want in onze westersche kwartieren gaat men niet gaarne over dag of midden op den dag uit, ten minste wij Europeanen niet, als er geen noodzaak voor is. Op Suriname maakt men wel, doch op de eilanden geen gebruik van parasols (alias parapluies) om de stralen der zon af te keeren; de hevige, voortdurende wind werpt die machines spoedig in duigen.

Noordelijk van de roomsch-katholieke kerk was het kerkhof of de begraafplaats aan die gemeente behoorende; ofschoon slecht onderhouden, was zij eveuwel ommuurd, met eene poort aan de oost- 
zijde; de graven werden door opgerigte kruisen aangewezen. Er was ook wel eene begraafplaats voor de protestanten, doch deze lag geheel open; later echter zijn er gelden bijeen gebragt, en is ook door hulp, welke het gouvernement verleende, die begraafplaats ommuurd en van een behoorlijken ingang voorzien.

Veel bijzonders zou ik verder omtrent Bonaire niet weten mede te deelen, omdat het niet mee te deelen is. Het eiland heeft nog veel boomgewas; doch daar het in den natuurstaat is, groeit alles door elkaar. Bịi behoorlijke bearbeiding zouden de boomen veel hooger opgroeijen en ook niet zoo onderhevig zijn aan zekere soort van parasietplanten, mos of champignon, dat zich aan de takken in groote bosschen hecht, den boom uitmergelt en eindelijk doet sterven. Er zijn.nog vele vlakke velden tusschen de bergen en de bosschen, geschikt ter bebouwing. Bij matigen regen zelfs is er genoegzaam voedsel voor het vee en de kabriet weet zich ook bij groote droogte nog wat voedsel van het laag geboomte en van de cactusplant te verschaften; doch het schaap en het rund kunnen zich daar niet mede voeden, wèl de ezel. De huizeu, die in de Savannah digt bij de reede liggen, zijn met dijkjes aan den hoofdweg verbouden, opdat de bewoners hunne woningen zouden kunnen verlaten als de Savaunah door zwaren regen onder water ligt; meermalen echter staat er zooveel water, dat die dijkjes en ook de hoofdweg onderliggen en dus de huizen volloopen, waardoor het dan in die woningen, vooral in zulke die geen bovenverdieping hebben, en de meeste hebben ze niet, lang zeer vochtig en daardoor ongezond blijft en de gemeenschap met de reede zoo goed als afgesloten is.

Alle benoodigdheden tot voeding, gemak en weelde worden van Curaçao aangebragt; zelfs wordt er niet altijd genoeg maïs geteeld, om allen te kunnen voeden, en al bragten de landen bij een goed regenjaar genoegzaam op, men wil dan toch wel iets anders eten dan zooals altijd gekookt maïsmeel, foensie geheeten; want om er brood van te bakken, is het maïsmeel niet geschikt. $\mathrm{Nu}$ heeft het eiland, behalve an vleesch, dat er zeer goedkoop is, aan pluimgedierte, dat er menigvuldig is, en aan visch, dien men ook goed en goedkoop kan krijgen, zoo wat gebrek aan alles. Groente, moes wordt er niet gekweekt, als een weinig. zooals ik reeds opgemerkt heb, op Fontein, en dat is nog maar voor soepgroenten. Eenige tuinen echter hebben eenige weinige vruchtboomen en leveren bij goeden regen meloenen op en pompoenen, 
welke laatste gekookt gegeten worden en van welke men ook eene soort van taart bereidt. Van het mäsmeel bakt men ook koeken, die men arepa's noemt, en met suiker of stroop gegeten, zeer smakelijk zijn; men gebruikt ze ook, bij gebrek aan brood, bij het vleesch. De proviand is op Bonaire, om aangeyoerde redenen, duur, doch daar er vele winkels zijn, te veel zelfs naar gelang van het klein getal inwoners, is er geen monopolie, en door de gezaghebbers wordt veel moeite gedaan, dat er geen heimelijke afpersing an de werklieden en landbouwers door de winkeliers kan worden gepleegd. Want het koopen en verkoopen is tusschen die beiden een ruilhandel; voor producten krijgen zij goederen en winkelwaren; en men kan wel begrijpen, dat daardoor nog al knevelarij kan worden gepleegd. Sterke drank wordt er nog al gesleten, want de arbeidende klasse is daarop zeer gesteld, en terwijl de fatsoeulijke man zijn rum met water des avonds drinkt, drinkt de gemeene man dien ook over dag, puur, zonder dat dit hem in de hitte schijnt te benadeelen. De melk is er overheerlijk en in overvloed, namelijk kabrietenmelk en die men ongewassen krijgt. Boter of kaas maakt men er thans niet meer; in vroegere jaren was dit wel het geval; deze werd dan onder de ambtenaren verdeeld en de slaven kregen de karnemelk.

De reden nu, dat het gouvernement zoowel plantages (een of meer zijn reeds uit de hand verkocht) als zoutpannen op Bonaire wil verkoopen, is, dunkt mij, daarin gelegen dat het zich zoo min mogelijk langer met de productie wil ophouden, maar die, zooals op de beide andere eilanden, aan particuliere industrie wil overlaten. En ik geloof, dat dit zeer wijs is gehandeld. Te voren toch, toen alle slaven, die op plantages en aan de zoutpaunen werkzaam waren, landsslaven waren (hoe dat die slaven allen landsslaven waren, is, meen ik, nooit helder aan het licht gekomen en thans behoeft dit niet meer gedaan te worden, nu door de emancipatie de slavernij vernietigd is) kostte het 't gouvernement weinig, naar rato ten minste, om het een en ander te doen bewerken; doch sedert de emancipatie zijn de bordjes verhangen en ofschoon dan ook op Bonaire geen hoog loon wordt betaald, moet er toch dagelijks arbeidsloon betaald worden en dat loopt in een jaar nog al wat op, terwijl ook nog de onderscheiden ambtenaars betaald moeten worden die er zeker het meest bij zullen verliezen; want komen die plantages en zoutpanuen in 
486 EENIGE BIJZONDERHEDEN OMTRENT HET EII.AND BONATRE.

particuliere handen, dan zullen die ambtenaren waarschijnlijk op pensioen worden gesteld. Te voren genoten zij ook het voordeel, dat zij landsslaven als huisbedienden kregen, zelfs soms wel, dat zij hen niet eens behoefden te voeden of te kleeden, maar de slaven daarenboven nog van het gouvernement kleeding en voedsel ontvingen. I $\mathrm{k}$ ben thans niet in staat, om het jaarlijksch verslag door het gouvernement aan de regering in het moederland ingediend, te raadplegen: maar zij die dat kunnen, zullen zeker wel zien dat de inkomsten van het gouvernement sedert de emancipatie zeer zijn afgenomen. Zooals ik, meen $\mathrm{ik}$, reeds opgaf, leverden de gouvernements-plantages, zelfs vóór de emancipatie, bijna niets op, of bragten zelfs schade aan, zoodat ook de kultuur van cochenille met die van aloë verwisseld werd.

Paramaribo, 16 Maart $1868 . \quad$ S. VAN Dissel. 